\title{
Managing Calico Scale (Hemiptera: Coccidae) Infestations on Landscape Trees
}

\author{
Jamee L. Hubbard and Daniel A. Potter
}

\begin{abstract}
Calico scale, Eulecanium cerasorum (Cockerell), an invasive pest of shade trees, has reached outbreak levels in landscapes and on horse farms in Kentucky, U.S. We evaluated efficacy and timing of conventional and reduced-risk foliar insecticides as well as trunk-injected or soil-applied systemics for managing E. cerasorum. Acephate, bifenthrin, carbaryl, cyfluthrin, and pyriproxyfen killed young settled crawlers on individually sprayed shoots. Whole-canopy pyrethroid sprays, however, gave $<66 \%$ control, underscoring the difficulty of reaching settled crawlers within large shade trees. Horticultural oil and insecticidal soap were relatively ineffective even with full spray coverage. Preventive sprays with bifenthrin or pyriproxyfen in mid-May, at first egg hatch, intercepted crawlers before they settled on leaves. Dormant oil failed to control overwintered nymphs or reduce subsequent numbers of adults or crawlers. A plant antitranspirant applied in late March provided 33\% suppression. Trunk-injected imidacloprid was ineffective, whereas dicrotophos (bidrin) gave at best $<50 \%$ control. Soil injection with imidacloprid in November, December, or March failed to reduce subsequent densities of adults on branches or crawlers on leaves. Reasons why it is difficult to eliminate calico scale in mature landscape trees are discussed in the context of the pest's feeding sites and behavior.
\end{abstract}

Key Words. Calico scale; Eulecanium cerasorum; integrated pest management; microinjection; plant health care; scale insects; systemic insecticide.

Calico scale, Eulecanium cerasorum (Cockerell), an invasive coccoid pest of shade and ornamental trees, has reached outbreak levels in Kentucky and elsewhere in the eastern United States (Hubbard and Potter 2005). Heavily infested hosts suffer twig and branch dieback and may be severely stressed or killed (Hubbard and Potter 2005). In spring, maturing females excrete copious honeydew that attracts wasps and other nuisance insects and promotes growth of unsightly sooty mold on bark and leaves. Honeydew falling on parked vehicles, decks, or other objects may require removal of infested trees. Highly susceptible hosts include maples (Acer spp.), sweetgum (Liquidambar styraciflua L.), honey locust (Gleditsia triacanthos L.), Japanese zelkova (Zelkova serrata [Thunb.] Makino) crabapples (Malus spp.), and other cultivated trees, as well as wild hackberry (Celtis occidentalis L.).

Calico scale is univoltine, overwintering as second instars on twigs, branches, and trunks and molting to the adult stage in late March to mid-April in Kentucky (Hubbard and Potter 2005; Figure 1). Females each produce several thousand eggs (mean, 3,700 to 4,700) beginning in late April. First egg hatch ranged from 21-26 May in 2001 to 2003 after mean accumulation of $818 \pm 2{ }^{\circ} \mathrm{C}$ degree days ( $1473 \pm 4^{\circ} \mathrm{F}$ degree days) from 1 January at $4.4^{\circ} \mathrm{C}\left(40^{\circ} \mathrm{F}\right)$ base temperature (Hubbard and Potter 2005). Female coloration fades from bright black with white spots to dull black with light to dark brown spots approximately 1 week before the first crawlers appear. Crawler dispersal lasts approximately 2 to 3 weeks, nearly all of them having settled on leaves by mid-June (Hubbard and Potter 2005). Crawlers may be windborne or remain on their tree of origin. Approximately mid-July, settled crawlers molt to second instars, which continue feeding on the leaves until just before leaf abscission in autumn, when they move to wintering sites on bark.

In central Kentucky, calico scale is a particular problem on thoroughbred horse farms where rows of single tree species are planted in narrow grassy strips between paved lanes and fenced pastures or paddocks. Labeled grazing restrictions, spray drift, concern about equine exposures, and associated liability preclude spraying broadly toxic pesticides on such sites (Potter et al. 2005). Similar issues occur when managing infestations in urban landscapes. This study evaluated reduced-risk chemical control of calico scale on horse farms and in urban landscapes.

\section{MATERIALS AND METHODS}

Thirteen trials evaluating strategies for controlling calico scale were conducted from June 2001 to May 2005. Eleven were conducted on horse farms in Fayette County or Woodford County, Kentucky, using rows of naturally infested, cultivated trees. A few trials were done on wild hackberry trees bordering pastures; two others used rows of cultivated sweetgums or Japanese zelkova along municipal roads. Trunk diameters, unless specified otherwise, ranged from 15 to $25 \mathrm{~cm}$

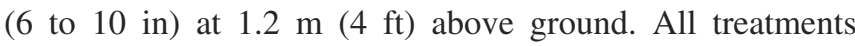




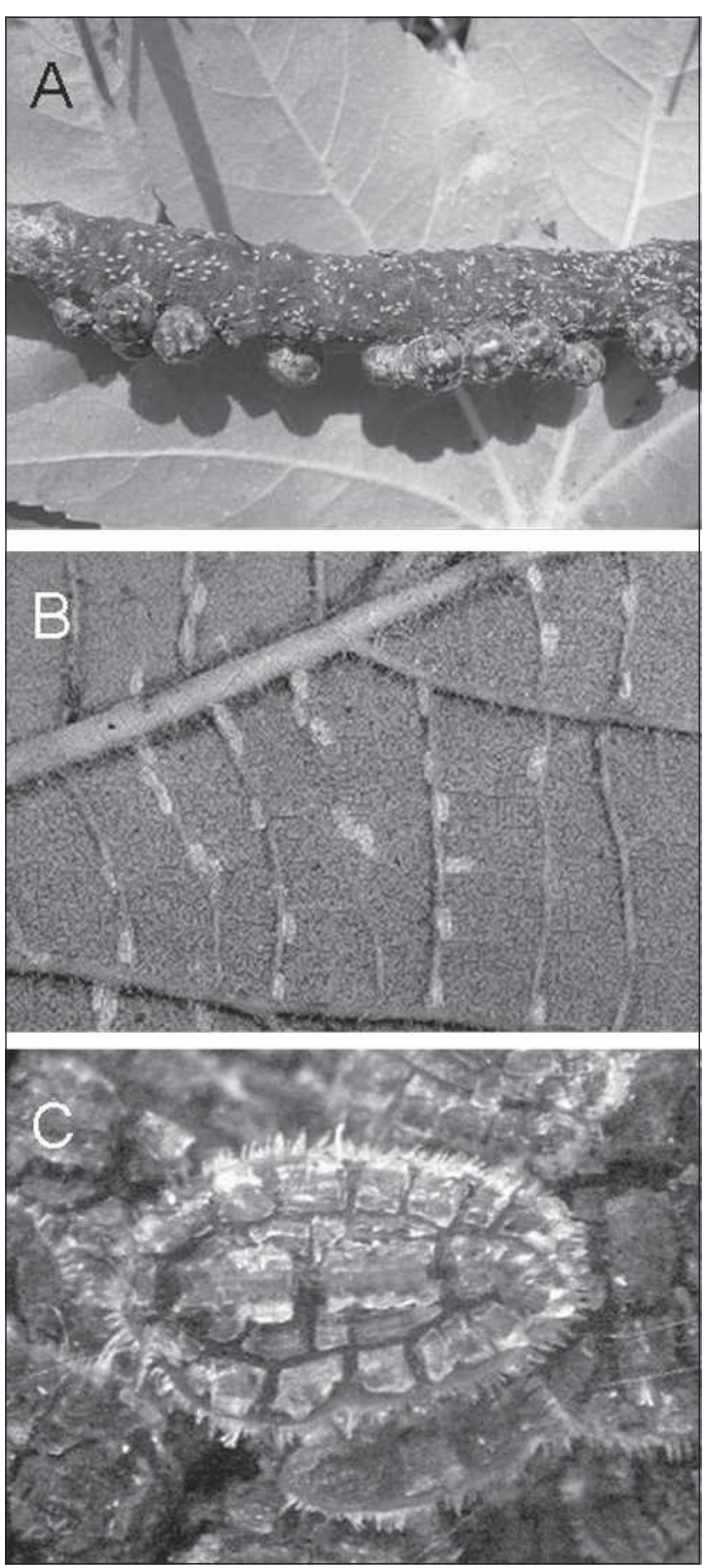

Figure 1. Life stages of calico scale targeted in this study: (A) crawlers hatching from beneath senescing and recently dead adult females in mid to late May; (B) settled crawlers along veins on abaxial leaf surface; (C) overwintering female nymph on bark showing dorsal wax plates. except for individual shoot sprays were applied by an experienced, ISA-certified arborist assisted by the authors. A nonionic surfactant (Break-thru; Goldschmidt Chemical, Hopewell, VA) was added at $0.31 \mathrm{~mL} / \mathrm{L}$ ( $4 \mathrm{oz} / 100 \mathrm{gal})$ to all spray mixes unless otherwise indicated.

For data analyses, percentages were arsine-transformed, and scale counts were log-transformed as necessary to correct for heterogeneity of variance. Treatment effects were analyzed by two- or one-way analysis of variance (ANOVA), depending on whether treatments were blocked, followed by Dunnett's test $(\alpha=0.05)$ for comparing treatments versus the control (Statistix 7.0; Analytical Software 2000). Paired $t$-tests were used for the soil injection trials having only two treatments. Data are reported as untransformed means \pm standard error (SE). Abbott's (1925) formula: corrected \% mortality $=[(\mathrm{y}-\mathrm{x}) / \mathrm{y}] \times 100]$ where $\mathrm{y}$ and $\mathrm{x}$ are percentage survival in control and treatment, respectively, was used to adjust for control mortality in trials evaluating foliar sprays or trunk-injected systemic insecticides to control crawlers. In such cases, both actual and adjusted mortality are reported.

\section{Foliar Sprays Targeting Settled Crawlers}

Three trials, intended to simulate whole-canopy sprays with optimal spray coverage, evaluated control of settled crawlers on leaves. Treatments were applied to separate tagged shoots and blocked within trees. Sprays were applied to runoff using 946-mL (1-qt) handheld trigger-type sprayers (Delta Sprayer; Delta Industries, North Hollywood, CA) held approximately $15 \mathrm{~cm}$ (6 in) from the foliage. Each insecticide was applied at the label rate for scale insects (Table 1).

The first trial was done in heavily infested sugar maples, Acer saccharum Marshall. Treatments were applied on 23 June 2001, 33 days after first observed crawler hatch, and included bifenthrin, acephate, insecticidal soap, insecticidal oil, and water only (Table 1). Tagged shoots were collected on 11 July (18 days after treatment), and numbers of dead and total settled crawlers on all leaves were counted with a binocular microscope at $25 \times$ magnification. Live settled crawlers are yellowish and turgid with angular wax plates covering the dorsum, whereas dead settled crawlers were orange to red, translucent, dehydrated, and paper-thin and sometimes missing the wax plates. The rationale for counting both dead and total crawlers was to account for crawlers that might have dropped or fallen from leaves after being affected by treatments.

The second trial, targeting settled crawlers later in the growing season, was blocked within six heavily infested hackberry trees. Sprays were applied on 20 July 2002, 55 days after first observed crawler hatch and approximately 5 days after settled crawlers began molting to second instars. Treatments were the same as previously mentioned, except that pyriproxyfen (Distance IGR) and carbaryl were added. Pyriproxyfen, a juvenile hormone analog with translaminar 
Table 1. Products and rates used in field trials against $E$. cerasorum.

\begin{tabular}{|c|c|c|c|}
\hline Active ingredient & Trade name ${ }^{\mathrm{z}}$ & AI $(\%)$ in product & Field rate ${ }^{\mathrm{y}}$ \\
\hline \multicolumn{4}{|l|}{ Foliage/bark spray formulations } \\
\hline Acephate & Orthene TTO & 75.0 & 787 mg/L (10.5 oz/100 gal) \\
\hline Bifenthrin & Talstar Lawn/Tree Flowable & 7.9 & $1.7 \mathrm{~mL} / \mathrm{L}(21.7 \mathrm{fl} \mathrm{oz} / 100 \mathrm{gal})$ \\
\hline Carbaryl & Sevin SL & 43.0 & $2.5 \mathrm{~mL} / \mathrm{L}(1 \mathrm{qt} / 100 \mathrm{gal})$ \\
\hline Cyfluthrin & Tempo SC Ultra & 1.8 & $0.41 \mathrm{~mL} / \mathrm{L}(5.4 \mathrm{fl} \mathrm{oz} / 100 \mathrm{gal})$ \\
\hline Horticultural oil & Superior Miscible Spray Oil & 95.0 & 20 to $30 \mathrm{~mL} / \mathrm{L}(2$ to $3 \mathrm{gal} / 100 \mathrm{gal})$ \\
\hline Insecticidal soap & Safer Yard \& Garden Insect Killer & 49.5 & $19.5 \mathrm{~mL} / \mathrm{L}(1.95 \mathrm{gal} / 100 \mathrm{gal})$ \\
\hline Pyriproxyfen & Esteem $35 \mathrm{WP}$ & 35.0 & $371 \mathrm{mg} / \mathrm{L}(5 \mathrm{oz} / 100 \mathrm{gal})$ \\
\hline Polyethylenes and polyterpenes & Transfilm & Not specified & 50 or $100 \mathrm{~mL} / \mathrm{L}(5$ or $10 \mathrm{gal} / 100 \mathrm{gal})$ \\
\hline \multicolumn{2}{|l|}{ Soil-injected formulation } & 75.0 & $1.96 \mathrm{~g} / 2.54 \mathrm{~cm}(0.07 \mathrm{oz} / 1 \mathrm{in})$ trunk diameter \\
\hline \multicolumn{4}{|l|}{ Trunk-injected formulations } \\
\hline Dicrotophos & Inject-a-cide "B" with bidrin & 82.0 & $2 \mathrm{~mL} / 5.1 \mathrm{~cm}(0.07 \mathrm{fl} \mathrm{oz} / 2 \mathrm{in})$ trunk diameter \\
\hline Imidacloprid & Imicide & 10.0 & $4 \mathrm{~mL} / 5.1 \mathrm{~cm}(0.14 \mathrm{fl} \mathrm{oz} / 2 \mathrm{in})$ trunk diameter \\
\hline
\end{tabular}

activity, is labeled for control of scale crawlers on ornamental trees. Carbaryl was included at farm managers' request. Efficacy was determined 13 days after treatment (2 August) in the same manner as previously described.

A third trial evaluated pyriproxyfen (Esteem $35 \mathrm{WP}$ ) against younger, settled crawlers. Cyfluthrin was included as a standard. Tagged shoots were blocked within five heavily infested hackberry trees. Sprays were applied on 23 June 2003, 29 days after the first observed crawler hatch and approximately 23 days before settled crawlers began molting to the second instar. Efficacy was determined on 31 July 2003 (38 days after treatment), as before.

\section{Preventive Sprays at First Crawler Hatch}

Controlling settled crawlers with contact insecticides requires that spray residues reach the nymphs, which nestle mainly along veins on abaxial leaf surfaces. We speculated that sprays applied at first egg hatch might be more effective than targeting settled crawlers because the active first instars would expose themselves to residues as they move from hatching sites on bark to feeding sites on leaves. That approach was tested in a stand of 6 to $8 \mathrm{~m}$ (19.8 to $26.4 \mathrm{ft})$ tall, heavily infested sweetgum trees planted along a grassy road median.

Three separate branches (each approximately $1 \mathrm{~m}$ long [3.3 $\mathrm{ft}$ ) bearing smaller twigs were blocked and tagged within six replicate trees. Tagged branches were encrusted with dozens of maturing female scales. The site was monitored daily for egg hatch, which began 20 May. That day, one tagged branch on each tree was sprayed with either bifenthrin or pyriproxyfen (Esteem 35 WP), or was left untreated. Treatments were applied with a backpack sprayer (Solo, Newport News, VA) to thoroughly wet the bark and leaves. The rest of the tree was not sprayed, ensuring ample crawlers to colonize the tagged shoots.

Efficacy was evaluated 3-4 August 2004 (75 to 76 days after crawler hatch) by harvesting each treated branch, removing 10 representative leaves along its length, and counting all live settled crawlers on the left half of the abaxial leaf surface of each leaf. Leaf counts were pooled within branches and compared between treatments with trees as replicates.

\section{Targeting Postoverwintered Scales with Insecticidal Oil or Antitranspirant}

Horticultural oil can be effective for controlling overwintering stages of certain soft scales (Johnson 1982; Baxendale and Johnson 1990). We evaluated late-winter oil sprays for control of late second instars and recently molted (not yet swollen) young adults on bark. For the first trial, lower branches (approximately $1 \mathrm{~m}$ long [3.3 ft]) were tagged and blocked within six heavily infested hackberry trees. Branches were sprayed to runoff with $2 \%$ or $3 \%$ insecticidal oil on 12 March 2002 or left unsprayed. Tagged branches were harvested on 24 April (43 days after treatment), cut into $12.7 \mathrm{~cm}$ (5.1 in) sections, and 15 randomly selected sections from each branch were examined with a binocular microscope at $25 \times$ to determine total living and dead scales. A second trial evaluated whole-canopy application of $2 \%$ insecticidal oil. Twelve heavily infested hackberry trees $(20$ to $25 \mathrm{~cm}$ [8 to 10 in] diameter) were randomly divided into treated or control groups. Treated trees were sprayed on 6 March 2002, using a hydraulic spray unit (Kappa-55; Udor, Lino Lakes, $\mathrm{MN}$ ) and spray gun having a $7 \mathrm{~mm}(0.28 \mathrm{in})$ diameter tip opening that delivered $38 \mathrm{~L}(10 \mathrm{gal}) / \mathrm{min}$ and $20.9 \mathrm{~kg} / \mathrm{cm}^{2}$ 
(300 lb/in ${ }^{2}$ ) pressure. Approximately $23 \mathrm{~L}$ (6 gal) of tank mix was applied to each canopy. Control trees were not sprayed. Twigs were collected from throughout the lower half of the canopy of each tree on 24 March and cut into $12.7 \mathrm{~cm}$ (5.1 in) lengths. Twenty pieces were randomly selected from each tree and examined as previously mentioned. Total live and dead scales and percentage mortality were analyzed as before.

Another trial evaluated some arborists' anecdotes that spraying postoverwintered nymphs with a horticultural antitranspirant (Transfilm; PBI/Gordon, Kansas City, MO) might control calico scale. Transfilm is an emulsion of polyethylenes and polyterpenes that, according to its label, coats the leaf surface to reduce water loss from transpiration and plant stress during storage, shipping, and establishment. Horticultural oil (2\%) was included for comparison. Treatments, including controls, were applied to separate tagged branches (1 to $3 \mathrm{~cm}$ [0.4 to $1.2 \mathrm{in}$ ] diameter, $1 \mathrm{~m}$ [3.3 ft] long) blocked within 10 heavily infested sweetgum trees. The antitranspirant was mixed with water at medium (5\%) and high (10\%) label rates. Treatments were applied on 29 March 2005, when nymphs were small, flat, and gray and evaluated in the field on 22 April 2005, by counting numbers of live, swollen black and white females on the first $46 \mathrm{~cm}$ (18.4 in) of twig length located apically beyond the tag.

\section{Trunk-Injected Systemic Insecticides Versus Whole-Canopy Sprays}

Four trials were done to evaluate timing and efficacy of trunk-injected systemic insecticides for managing calico scale. The Mauget MicroInjection System (J.J. Mauget, Arcadia, CA) wherein therapeutic chemicals in sealed capsules are introduced through tubes inserted into shallow holes (4.0 $\mathrm{mm}$ [0.16 in] diameter) drilled in the root flare (Tattar et al. 1998), was used for trunk injections. Products evaluated were $82 \%$ dicrotophos (Inject-a-cide B [bidrin]; Mauget; 2 $\mathrm{mL}[0.06 \mathrm{fl} \mathrm{oz}]$ capsules) and $10 \%$ imidacloprid (Imicide; Mauget; $4 \mathrm{~mL}$ [0.12 fl oz] capsules) at label rate: one capsule per $5.1 \mathrm{~cm} \mathrm{(2} \mathrm{in)} \mathrm{of} \mathrm{trunk} \mathrm{diameter.} \mathrm{For} \mathrm{comparison,} \mathrm{two} \mathrm{of}$ the trials included whole-canopy sprays with bifenthrin (Talstar Lawn and Tree Flowable, FMC, Philadelphia, PA) at label rate (Table 1). The bifenthrin tank mix included a surfactant, as before, and was applied with the same hydraulic spray unit described for the whole-canopy oil applications. Imidacloprid was injected earlier than other treatments because it can take as long as 1 month to fully translocate to leaves (Tattar et al. 1998), whereas dicrotophos translocates in a few days and bifenthrin has immediate contact activity. Untreated control trees were included in each trial. Trees were assigned to treatments (i.e., blocked) by visual estimate of initial infestation level.

Trial 1 compared activity of whole-canopy bifenthrin sprays applied soon after crawler hatch versus trunk-injected dicrotophos targeting relatively young settled crawlers. Treatments were replicated five times using heavily infested sugar maple trees ( 25 to $36 \mathrm{~cm}$ [10 to 14.4 in] diameter). Bifenthrin sprays were applied on 29 May 2001, 8 days after the first crawlers were observed. Dicrotophos was injected on 28 June 2001. Fifty leaves were sampled from throughout the lower half of the canopy of each tree on 15 July 2001, 47 and 17 days, respectively, after the spray or systemic treatments. All live and dead crawlers were counted, and percentage mortality was determined as before.

Trial 2 compared efficacy of injected dicrotophos and imidacloprid against settled crawlers on sweetgum leaves. Treatments were replicated four times with separate trees ( 25 to 46 $\mathrm{cm}$ [10 to $18.4 \mathrm{in}$ ] diameter) as replicates. Trees were injected on 31 July 2002, 66 days after first observed crawler hatch. Efficacy was evaluated on 28 September (59 days after treatment) by sampling 25 leaves from throughout the lower half of each tree's canopy and examining all settled crawlers. The same trees were sampled again on 19-20 May 2003, to evaluate any differences in subsequent adult populations. Twenty $50 \mathrm{~cm}$ long twigs were arbitrarily sampled from each tree canopy. Numbers of adults were counted and compared among treatments as before.

Trial 3, conducted from May to September 2003, used cultivated, heavily infested sweetgum trees ( 25 to $40 \mathrm{~cm}$ [10 to $16 \mathrm{in]}$ diameter, five replications per treatment). Treatments were imidacloprid and dicrotophos injected at the aforementioned rates, plus bifenthrin whole-canopy sprays and untreated controls. Imidacloprid was injected on 23 May, 2 days before first crawler hatch, whereas dicrotophos and bifenthrin treatments were on 2 July. Efficacy was evaluated by sampling 25 leaves from throughout the lower half of the canopy of each tree on 7 August 2003, and counting dead and total settled crawlers per sample.

Trial 4, also conducted in 2003, compared imidacloprid injected on 20 May (5 days before crawler hatch) versus dicrotophos applied on 2 July for controlling calico scale crawlers in a stand of zelkova trees (15 to $25 \mathrm{~cm}$ [6 to $10 \mathrm{in}$ ] diameter). Treatments were randomly assigned to five trees per treatment blocked by infestation level. Efficacy was determined by sampling 100 leaflets from each tree on 22 July 2003, and counting crawlers as before.

\section{Whole-Tree Treatments with Soil-Injected Imidacloprid}

Imidacloprid is labeled for soil injection for systemic control of sucking insects on woody plants. Label directions specify that injection holes be in a grid or circular pattern extending to the tree's drip line or else be evenly spaced around the trunk no more than 15 to $30 \mathrm{~cm}$ (6 to $12 \mathrm{in}$ ) from its base. The label states that because translocation may take 60 days or longer, applications should be made before anticipated pest 
injury. Soil injection seemingly is well-suited for horse farms or other sites where spray drift is a concern.

The first trial evaluated imidacloprid applied through soil injection when trees were dormant, targeting postoverwintered nymphs and adults and the subsequent generation of settled crawlers. We used rows of infested sugar maples (10 to $13 \mathrm{~cm}$ [4 to $5.2 \mathrm{in}$ ] diameter) along a horse farm lane, blocking seven replicates of treated and control trees by visual estimate of initial infestation level. Treated trees received imidacloprid (Merit $75 \mathrm{WP}$; Bayer, Montvale, NJ) at the high label rate $(1.96 \mathrm{~g}[0.07 \mathrm{oz}]$ product per $2.54 \mathrm{~cm}[1.02$ in] trunk diameter) either on 19 December 2001, or 3 March 2002. A Kioritz 100 soil injector (Wilbur-Ellis, Seattle, WA) was used to inject the insecticide/water solution (64 g product/L [8.5 oz/gal]; $11.8 \mathrm{~mL} / \mathrm{cm}$ [1 fl oz/in] trunk diameter) approximately $15 \mathrm{~cm}$ (6 in) deep in a circular pattern around the drip line of treated trees.

Adult female scales were sampled on 6 May 2002, 138 days and 64 days, respectively, after the 19 December or 3 March treatments. On these relatively small trees, most adults were situated on basal portions of lower branches and along the main trunk; therefore, live scales were counted on the main trunk to $3 \mathrm{~m}(9.9 \mathrm{ft})$ height and on the basal $30.5 \mathrm{~cm}$ (12.2 in) of the lowest four branches. Settled crawlers were examined on 17 June 2002 (180 days and 106 days, respectively, after the December or March treatments). Fifty leaves were collected from throughout each tree's canopy and numbers of dead and total crawlers, and percentage mortality, were analyzed as before.

We also evaluated high-volume soil injection with imidacloprid in late autumn to control calico scale the next growing season. Twelve red maples (approximately $10 \mathrm{~cm}$ [4 in] diameter) were paired according to the previous year's infestation level. The soil around one tree of each pair was treated with imidacloprid (Merit $75 \mathrm{WP})$ at $1.96 \mathrm{~g}(0.07 \mathrm{oz})$ product per $2.54 \mathrm{~cm}$ (1.02 in) of trunk diameter (the highest label rate) on 25 November 2003. A high-pressure injection system (Kappa-55 3-piston pump; Udor, Italy) with a $1.9 \mathrm{~cm}(0.76$ in) diameter wand having four $2.38 \mathrm{~mm}$ (0.95 in) holes at right angles was used to apply $1.92 \mathrm{~L}(64 \mathrm{fl} \mathrm{oz})$ per tree with $147.9 \mathrm{~mL}(4.44 \mathrm{fl} \mathrm{oz})$ applied per injection point and 13 injection points located 25.4 to $30.5 \mathrm{~cm}$ (10.16 to $12.2 \mathrm{in}$ ) from the trunk and evenly spaced around the tree. Injection pressure was $7.0 \mathrm{~kg} / \mathrm{cm}^{2}\left(100 \mathrm{lb} / \mathrm{in}^{2}\right)$.

Efficacy against the overwintering generation, nymphs of which were present when the injections were done, was evaluated on 10 May 2004 (167 days after injections). We counted live adult females on the main trunk to $2.3 \mathrm{~m}(7.6 \mathrm{ft})$ height and $46 \mathrm{~cm}$ (18.4 in) along four main branches beyond the point of attachment to the trunk. Counts were totaled per tree and compared between treatments by paired $t$-test. Control of subsequent crawlers on leaves was evaluated on 10 August 2004 (259 days after injections). For those samples, a pole pruner was used to harvest 16 woody twigs with foliage throughout each tree's canopy. Live and dead settled crawlers were counted on the left half of the abaxial surface of one fully expanded leaf per twig. Data were pooled within trees and analyzed as described earlier.

\section{RESULTS}

\section{Foliar Sprays Targeting Settled Crawlers}

Acephate, bifenthrin, and carbaryl gave excellent (90\% to $100 \%$ ) control of settled crawlers on individually sprayed shoots (Table 2, trials 1 and 2). In contrast, $2 \%$ horticultural oil was only marginally effective, even with complete spray coverage. Insecticidal soap partially suppressed young settled crawlers treated during June 2001 (33 days after first crawler hatch), but was ineffective against older crawlers treated during July 2002 (55 days after first crawler hatch). Pyriproxyfen, too, was ineffective with July 2002 treatment timing. Total (live and dead) crawlers did not differ between treatments, indicating that dead crawlers remained on the leaves (Table 2).

Pyriproxyfen was more effective with earlier treatment targeting relatively young settled crawlers. Application on 23 June 2003, 29 days after first egg hatch, resulted in $88.6 \pm$ $3.9 \%$ settled crawler mortality compared with $99.4 \pm 0.4 \%$ from cyfluthrin and $4.8 \pm 1.2 \%$ mortality within the controls $(F=385.3 ; \mathrm{df}=2,14 ; P<0.0001$; Table 2, trial 3).

\section{Preventive Sprays at First Crawler Hatch}

Bifenthrin or pyriproxyfen applied at first egg hatch reduced numbers of live settled crawlers on leaves by $93 \%$ and $63 \%$ relative to untreated control branches. Mean $( \pm \mathrm{SE})$ number of live crawlers per leaf sample from those treatments averaged $85 \pm 106,425 \pm 140$, and $1142 \pm 273$, respectively $(F=7.46$; $\mathrm{df}=2,10 ; P=0.01)$.

\section{Targeting Postoverwintered Scales with Insecticidal Oil or Antitranspirant}

Spraying individual hackberry branches to runoff with $2 \%$ or $3 \%$ horticultural oil on 12 March, before budbreak, failed to control scale infestations on the bark. Infestation levels were comparable on twigs assigned to the different treatments, averaging $64.5 \pm 12.1$ per $1.9 \mathrm{~m}(6.3 \mathrm{ft})$ of twig length. Mortality averaged $56.6 \pm 5.5,68.2 \pm 9.2$, and $53.2 \pm 7.3$ for untreated, $2 \%$ and $3 \%$ oil, respectively, with no increase from the oil sprays $(F=6.75$, df $=2,17 ; P=0.30)$. Similarly, spraying whole hackberry trees with horticultural oil on 6 March failed to provide significant control. Scale densities per $2.54 \mathrm{~m}(8.4 \mathrm{ft})$ of twig length averaged $322 \pm 69$ and 344 $\pm 76(F=0.05 ; \mathrm{df}=1,11 ; P=0.83)$ and percentage mortality averaged $39.9 \pm 4.2$ versus $40.8 \pm 5.2(F=0.01$; $\mathrm{df}=1,11 ; P=0.91)$ for untreated versus treated branches, respectively. 
Table 2. Efficacy of foliar insecticides applied at label rate for scale insects (see text) against settled calico scale crawlers on leaves of individually sprayed shoots.

\begin{tabular}{|c|c|c|c|}
\hline Trial and treatment & Crawlers per shoot ${ }^{\mathrm{z}}$ & Percent mortality ${ }^{\mathrm{y}}$ & Adjusted percent mortality ${ }^{\mathrm{x}}$ \\
\hline \multicolumn{4}{|c|}{ Trial 1, treated 23 June 2001, on sugar maple } \\
\hline Control & $544 \pm 126$ & $27.7 \pm 4.5$ & $0.0 \pm 0.0$ \\
\hline Insecticidal soap & $482 \pm 87$ & $50.0 \pm 7.8 *$ & $32.6 \pm 7.5$ \\
\hline Horticultural oil & $515 \pm 80$ & $54.5 \pm 7.9 *$ & $37.7 \pm 9.7$ \\
\hline Bifenthrin & $478 \pm 99$ & $96.8 \pm 1.9^{*}$ & $94.4 \pm 2.8$ \\
\hline Acephate & $638 \pm 161$ & $100.0 \pm 0.0 *$ & $100.0 \pm 0.0$ \\
\hline \multicolumn{4}{|c|}{ Trial 2, treated 22 July 2002, on hackberry } \\
\hline Control & $1375 \pm 192$ & $10.2 \pm 2.5$ & $0.0 \pm 0.0$ \\
\hline Insecticidal soap & $1230 \pm 151$ & $7.7 \pm 1.8$ & $0.7 \pm 0.7$ \\
\hline Pyriproxyfen & $1388 \pm 303$ & $8.7 \pm 1.6$ & $2.8 \pm 0.4$ \\
\hline Horticultural oil & $1930 \pm 843$ & $54.5 \pm 13.4^{*}$ & $50.2 \pm 14.0$ \\
\hline Bifenthrin & $1139 \pm 208$ & $90.2 \pm 3.2 *$ & $89.0 \pm 3.7$ \\
\hline Acephate & $1328 \pm 361$ & $99.2 \pm 0.3 *$ & $99.1 \pm 0.3$ \\
\hline Carbaryl & $855 \pm 132$ & $100.0 \pm 0.0^{*}$ & $100.0 \pm 0.0$ \\
\hline \multicolumn{4}{|c|}{ Trial 3, treated 23 June 2003, on hackberry } \\
\hline Control & $1609 \pm 230$ & $4.8 \pm 1.2$ & $0.0 \pm 0.0$ \\
\hline Pyriproxyfen & $982 \pm 135$ & $88.6 \pm 3.9 *$ & $87.8 \pm 4.3$ \\
\hline Cyfluthrin & $1291 \pm 368$ & $99.4 \pm 0.4 *$ & $99.4 \pm 0.4$ \\
\hline
\end{tabular}

${ }^{\mathrm{z}}$ Mean total crawlers does not differ significantly among treatments in any trial (two-way ANOVA, $P>0.32$ ).

${ }^{y}$ ANOVA results: trial $1: F=79.3 ; \mathrm{df}=4,35 ; P<0.001$; trial $2: F=91.4 ; \mathrm{df}=6,40 ; P<0.001$; trial $3: F=385.3 ; \mathrm{df}=2,14 ; P<0.0001$.

${ }^{\mathrm{x}}$ Abbott's (1925) formula used to adjust for mortality in untreated controls.

Data are means ( \pm standard error); efficacy was evaluated 18,13 , and 38 days after treatment in trials $1-3$, respectively. Within trials and columns, means followed by an asterisk $(*)$ differ significantly from the untreated control (Dunnett's test, $\alpha=0.05$ ).

Spraying overwintered nymphs on branches with $2 \%$ horticultural oil or 5\% Transfilm solution on 29 March failed to reduce the number maturing to adults, but the high (10\%) rate of antitranspirant resulted in 33\% suppression, significant by Dunnett's test $(P<0.05)$ from the untreated control. Live adult scales per $47 \mathrm{~cm}$ (18.8 in) of twig averaged $76.5 \pm 19.1$ on control branches versus $59.7 \pm 14.1,80.7 \pm 12.7$, and 51.4 \pm 12.0 for oil, low and high rates of Transfilm, respectively $(F=3.15 ; \mathrm{df}=3,27 ; P=0.04)$.

\section{Trunk-Injected Systemic Insecticides Versus Whole-Canopy Sprays}

Whole-canopy sprays with bifenthrin approximately 1 week after first egg hatch resulted in significant (65.6\%) mortality of calico scale crawlers in sugar maples as compared with $28.9 \%$ natural mortality in controls (Table 3, trial 1). Trunk injection with dicrotophos in late June, however, did not provide significant control in the same trial. When sweetgum trees were injected in late July (trial 2), significant control was obtained from dicrotophos, but not imidacloprid. Neither treatment, however, resulted in significantly lower adult populations on treated trees the next spring (Table 3). Neither imidacloprid nor dicrotophos (injected in late May or early July, respectively) controlled crawlers on sweetgum trees in trial 3, but canopy sprays with bifenthrin gave some suppression (Table 3). Dicrotophos provided partial control on zel- kova in trial 4, but imidacloprid again was ineffective (Table 3 ). Total (live plus dead) crawlers did not differ among treatments in any trial, confirming that initial infestations were comparable and that dead crawlers remained on leaves.

\section{Whole-Tree Treatments with Soil-Injected imidacloprid}

Imidacloprid injected around the drip line using the Kioritz soil injector on 19 December 2001, or 3 March 2002, failed to control calico scale on medium-sized sugar maples. Mean $( \pm$ SE) numbers of swollen females maturing on sampled branches in May 2002 were $229 \pm 132,203 \pm 116$, and 153 \pm 67 for control trees and the December and March treatments, respectively $(F=0.13$; df $=2,20 ; P=0.88)$. Similarly, neither treatment timing reduced subsequent numbers of crawlers on leaves $(2952 \pm 1544,1653 \pm 814,3,000 \pm$ 1111 , respectively, per sample; $F=0.41 ; \mathrm{df}=2,20 ; P=0.67$ ) or increased the percentage of dead crawlers by mid-June $2002(9.3 \pm 2.1,8.0 \pm 0.9,9.7 \pm 0.9 \%$, respectively; $F=0.44$; $\mathrm{df}=2,17 ; P=0.66)$.

High-volume, basal soil injection with imidacloprid in late November 2003 also failed to control calico scales on sugar maples. On 10 May 2004, treated trees had an average of 318 \pm 86 adult females on sampled branches versus $118 \pm 45$ for controls $(t=1.69 ; \mathrm{df}=5 ; P=0.15)$. In August, live settled crawlers on leaves averaged $677 \pm 189$ per sample for treated 
Table 3. Evaluation of trunk-injected systemic insecticides (TI) or whole-canopy sprays (CS) for controlling calico scale on three tree species.

\begin{tabular}{|c|c|c|c|c|c|c|c|}
\hline \multirow[b]{2}{*}{ Trial } & \multirow[b]{2}{*}{ Host (year) } & \multirow[b]{2}{*}{ Treatment } & \multirow[b]{2}{*}{ Method } & \multirow[b]{2}{*}{ Treatment date } & \multicolumn{3}{|c|}{ Crawlers per sample ${ }^{\mathrm{z}}$} \\
\hline & & & & & Total & Percent mortality ${ }^{\mathrm{y}}$ & Adjusted percent mortality ${ }^{\mathrm{x}}$ \\
\hline \multirow[t]{3}{*}{1} & \multirow{3}{*}{$\begin{array}{l}\text { Sugar maple } \\
(2001)\end{array}$} & Dicrotophos & TI & 28 June & $2489 \pm 459$ & $42.0 \pm 2.8$ & $24.7 \pm 3.6$ \\
\hline & & Bifenthrin & $\mathrm{CS}$ & 29 May & $1931 \pm 586$ & $65.6 \pm 9.3^{*}$ & $55.4 \pm 12.1$ \\
\hline & & Control & - & - & $4701 \pm 1688$ & $28.9 \pm 5.0$ & - \\
\hline \multirow[t]{3}{*}{2} & \multirow{3}{*}{$\begin{array}{l}\text { Sweetgum } \\
(2002)\end{array}$} & Dicrotophos & $\mathrm{TI}$ & 31 July & $3344 \pm 811$ & $55.8 \pm 15.3^{*}$ & $48.1 \pm 17.9$ \\
\hline & & Imidacloprid & TI & 31 July & $4145 \pm 756$ & $22.3 \pm 2.3$ & $8.8 \pm 2.6$ \\
\hline & & Control & - & - & $2562 \pm 756$ & $14.8 \pm 1.9$ & - \\
\hline \multirow[t]{4}{*}{3} & \multirow{4}{*}{$\begin{array}{l}\text { Sweetgum } \\
(2003)\end{array}$} & Dicrotophos & TI & 2 July & $2896 \pm 613$ & $39.0 \pm 11.4$ & $23.2 \pm 13.6$ \\
\hline & & Imidacloprid & TI & 23 May & $2353 \pm 692$ & $9.4 \pm 3.4$ & $0 \pm 0$ \\
\hline & & Bifenthrin & $\mathrm{CS}$ & 2 July & $3860 \pm 1065$ & $54.0 \pm 7.0^{*}$ & $39.9 \pm 9.2$ \\
\hline & & Control & - & - & $2083 \pm 905$ & $23.4 \pm 12.5$ & - \\
\hline \multirow[t]{3}{*}{4} & \multirow{3}{*}{$\begin{array}{l}\text { Zelkova } \\
(2003)\end{array}$} & Dicrotophos & $\mathrm{TI}$ & 2 July & $314 \pm 105$ & $53.0 \pm 11.2 *$ & $43.1 \pm 13.5$ \\
\hline & & Imidacloprid & $\mathrm{TI}$ & 20 May & $560 \pm 185$ & $17.0 \pm 3.2$ & $0 \pm 0$ \\
\hline & & Control & - & 2 July & $779 \pm 172$ & $17.4 \pm 0.2$ & - \\
\hline
\end{tabular}

${ }^{\mathrm{z}}$ Evaluation dates were 15 July, 28 September, 7 August, and 22 July for trials 1-4, respectively. Total (live and dead) crawlers per sample did not significantly differ between treatments in any trial.

${ }^{\mathrm{y}}$ For percent mortality, an asterisk $(*)$ denotes means that differ significantly from the control within that trial (ANOVA, Dunnett's test, $P<0.05$ ).

xAbbott's (1925) formula used to adjust for mortality in untreated controls.

trees versus $603 \pm 239$ per sample for controls $(t=0.28$; df $=5 ; P=0.79)$.

\section{DISCUSSION}

Proximity of infested trees to pastures poses challenges when managing calico scale on horse farms. Labels for many foliar insecticides used by arborists specify grazing restrictions. Most farm managers will not spray pesticides where horses might be exposed to aerial spray drift or to residues on grass or hay. Similar concerns often apply when managing outbreaks on street or shade trees in landscape settings.

Of those insecticides effective against calico scale crawlers in our trials, bifenthrin and cyfluthrin have no grazing restrictions. Carbaryl, used on horse farms to control pests (e.g., Japanese beetles) on ornamentals, is labeled for use on pastures and rangeland. Nevertheless, in our experience, farm managers are hesitant to use pyrethroids or carbaryl near sites where horses may graze. Acephate, an organophosphate with contact and translaminar systemic activity, is labeled for scale crawlers on trees but has grazing restrictions. Pyriproxyfen, a juvenile hormone analog that has activity against crawlers of other scale insects (Rebek and Sadof 2003), has a favorable toxicologic profile and no grazing restrictions. In our trials, it controlled young calico scale crawlers in May and June but was ineffective later in summer once settled crawlers had begun molting to second instars. Use with a surfactant may be required; without surfactant, the spray mix beaded up on leaves and gave poor control (Hubbard 2004).
Several aspects of calico scale biology confound efforts to manage the pest with contact insecticides (Hubbard and Potter 2005). Crawlers settle mainly on leaf undersides along the midrib and major veins. They are abundant throughout the canopy and within shoots are concentrated on the inner (basal) leaves. Thus, hydraulic sprays targeting settled crawlers are unlikely to provide more than partial suppression of infestations in tall landscape trees. Females each produce thousands of eggs, and crawler dispersal occurs over several weeks during which contact insecticide residues become increasingly depleted. Wild host plants, especially highly susceptible hackberry, which is ubiquitous on Kentucky horse farms, are a reservoir for windborne crawlers that infest nearby cultivated trees.

We made evaluations to determine if applying a residual contact insecticide at first egg hatch would intercept the crawlers as they dispersed over treated bark and foliage. Bifenthrin or pyriproxyfen applied in that manner reduced colonization of individually sprayed branches in heavily infested sweetgum trees by $93 \%$ and $63 \%$, respectively. Because most of each tree was untreated, enormous numbers of crawlers were left alive to challenge the sprayed branches. The strategy likely would be even more effective if the whole canopy were sprayed.

Canopy sprays to control tree-feeding pests can negatively impact natural enemies with potential for pest resurgence (Raupp et al. 2001). Parasitism rates, at least in central Kentucky, however, are relatively low $(<30 \%)$ and the para- 
sitoid-predator complex does not seem to prevent the scales from reaching high densities, even on minimally managed or wild hosts (Hubbard and Potter 2005). In Kentucky, adult parasitoids associated with calico scale are most active in April to early May, and from July through October, so short residual contact insecticides targeting recently hatched crawlers in late May or June will likely have relatively little impact on parasitism rates.

Horticultural oil sprays are effective against many scale insect species (Johnson 1982; Baxendale and Johnson 1990), although often they provide only partial control (e.g., Turner and Buss 2005). In our trials, horticultural oil applied with optimal coverage gave just $38 \%$ to $50 \%$ corrected mortality of settled crawlers (Table 2). Unlike some soft scales that have only a thin dorsal layer of wax, calico scale nymphs produce heavy angular wax plates as they mature (Gill 1988, Figure 1). That wax may reduce vulnerability of crawlers to soaps and oils. Given the 2- to 3-week hatching window and location of settled crawlers, it is unlikely that soaps, oils, or other "soft" contact insecticides requiring full spray coverage will effectively control calico scale in large trees. Dormant oil sprays targeting late second instars and young adults also were ineffective in our trials.

Trunk-injected or soil-applied systemic insecticides are suited for sites such as horse farms where aerial spray drift is a concern (Tattar et al. 1998; Potter et al. 2005). Trunk microinjection with dicrotophos (bidrin) can be highly effective against some tree-feeding insects (e.g., McClure 1992; Potter et al. 2005). Although that tactic suppressed calico scale crawlers in three of our four trials, adjusted control was only $43 \%$ to $55 \%$ (Table 3). Within-tree control also was inconsistent; crawler mortality often ranged from $0 \%$ to $100 \%$ on leaves from different branches or canopy zones (Hubbard 2004). Trunk- or soil-injected imidacloprid often provides good control of aphids (Sclar and Cranshaw 1996) adelgids (Steward and Horner 1994), psyllids (Young 2002), lace bugs (Gill et al. 1999), certain scales (Sclar and Cranshaw 1996), and other tree pests. In our trials, however, imidacloprid failed to control any life stage of calico scale regardless of whether applied by trunk injection in spring or summer or by soil injection in autumn, winter, or spring.

Translocation of systemic insecticides is affected by tree vitality and health of the transport tissues and may be impeded by old wounds, cankers, or scarring in trunk or branch tissues (Doccola et al. 2005). Species, size, and age of treated trees, environmental factors (e.g., drought, soil and air temperature), and time of year can affect translocation (Tattar et al. 1998), and efficacy may also depend on the specific tissues on which the target pest feeds (Rebek and Sadof 2003). Such interactions are poorly understood, so we cannot pinpoint why dicrotophos was erratic and imidacloprid was ineffective against calico scale. Our study trees generally were in rural, favorable growing sites, the trials involved different tree species and were done over several years, and the applications were made by an experienced, ISA-certified arborist. Trunk-injected imidacloprid controlled aphids and psyllids on large pin oak and eucalyptus trees, respectively, within 1 week after treatment (Tattar et al. 1998; Young 2002), and trunk-injected dicrotophos killed tent caterpillars in tall cherry trees within a few days (Potter et al. 2005). In contrast, several months may be required for soil-applied imidacloprid to be fully translocated within large trees (Tattar et al. 1998). Regardless, there should have been ample time for both our soil applications and trunk injections to reach their targets.

Although specific feeding sites of calico scale life stages within plant tissues have not been studied, it is noteworthy that neither settled crawlers nor overwintering nymphs produce noticeable honey. Rebek and Sadof (2003) suggested that lack of translocation beyond vascular tissue may account for imidacloprid's poor efficacy against euonymus scale, Unaspis euonymi (Comstock), which feeds on subcuticular plant cell contents rather than phloem. Similar limitations may account for its failure to control calico scale crawlers. The spatial distribution of settled crawlers in relation to leaf veins differs markedly on different hosts (Hubbard and Potter 2005), which might also contribute to variable performance of systemic insecticides. Adult female calico scales produce copious honeydew, indicative of phloem-feeding, but if upward translocation of imidacloprid through xylem deposits the insecticide mainly in bud and leaf tissues, perhaps not enough moves back down the phloem to control scales feeding through the bark of branches and trunks. Additional research on how systemic insecticides move within trees may help clarify why some pests are more readily controlled than others, and why better control of calico scale was not obtained by that approach.

\section{IMPLICATIONS FOR ARBORICULTURE}

Calico scale, an invasive soft scale, is a severe pest of maples, sweetgum, honeylocust, crabapple, and other tree species in the eastern United States. Nymphs overwinter on bark, producing copious honeydew as they mature in spring. Eggs hatch in late May, approximately a week after adult coloration fades from bright black and white to dull brown, and crawlers migrate to leaves where they feed until autumn. Hydraulic sprays targeting settled crawlers in summer likely will provide only partial control because they fail to reach all the tiny, waxy nymphs nestled along leaf veins. Treating at first egg hatch may be more effective by intercepting motile crawlers as they disperse over treated bark and leaves. Several foliar insecticides (bifenthrin, cyfluthrin, acephate, carbaryl, pyriproxyfen) are active against settled crawlers, but insecticidal soap and summer or dormant oils were ineffective in our trials. Trunk-injected dicrotophos (bidrin) gave partial ( $40 \%$ to $50 \%$ ) mortality of settled crawlers, but trunk- 
or soil-injected imidacloprid failed to systemically control calico scale regardless of treatment timing.

\section{ADDENDUM}

In a later trial that did not undergo technical review with the rest of this paper, calico scale females on branches of heavily infested zelkova trees were sprayed with $7.9 \%$ bifenthrin (TalstarOne, FMC, Philadelphia, PA) at $1.6 \mathrm{ml} / \mathrm{L}$ (20 fl oz/ $100 \mathrm{gal}$ ) with $0.31 \mathrm{ml} / \mathrm{L} \mathrm{(4} \mathrm{oz/100} \mathrm{gal)} \mathrm{surfactant} \mathrm{(Break-thru,}$ now marketed as CapSil Spray Adjuvant, Scotts, Marysville, $\mathrm{OH}$ ) on 20 April 2006. At that time, the maturing scales were swollen, 3 to $4 \mathrm{~mm}$ (1/8 inch) in diameter, and producing profuse honeydew. There was $100 \%$ mortality of sprayed females within $5 \mathrm{~d}$, stopping honeydew and egg production.

Acknowledgments. We are grateful to L.M. Hanks (Consulting Arborist, Pampered Properties, Inc.) for cooperation and applying the whole-canopy sprays and systemic treatments; D. Held, C. Prater, C. Hagen, P. Gonsiska, and C. Redmond for field assistance; and L.M. Hanks, D. Herms (Ohio State University), and T. Tattar (University of Massachusetts) for advice. Horticulturalists at Gainesway, Gainesborough, and Overbrook Farms provided access to study sites. We also thank J.J. Mauget Co. (Arcadia, CA) and other companies (see footnote, Table 1) for donating insecticides. This research was funded in part by the University of Kentucky Nursery Endowment Fund.

\section{LITERATURE CITED}

Abbott, W.S. 1925. A method of computing the effectiveness of an insecticide. Journal of Economic Entomology 18: 265-267.

Analytical Software. 2000. Statistix 7.0 user's manual. Analytical Software, Tallahassee, FL.

Baxendale, R.W., and W.T. Johnson. 1990. Efficacy of summer oil spray on thirteen commonly occurring insect pests. Journal of Arboriculture 16:89-94.

Doccola, J.J., I. Ramasamy, P. Castillo, C. Taylor, and S. Sifleet. 2005. Erratum: Efficacy of Arborjet Viper microinjections in the management of hemlock wooly adelgid (Adelges tsugae). Journal of Arboriculture 31:203-205.

Gill, R.J. 1988. The Scale Insects of California. Part I: The Soft Scales (Homoptera: Coccoidea: Coccidae). California Department of Food and Agriculture, Sacramento, CA.

Gill, S., O.K. Jefferson, R.M. Reeser, and M.J. Raupp. 1999. Use of soil and trunk injection of systemic insecticides to control lace bug on hawthorn. Journal of Arboriculture 25:38-41.

Hubbard, J.L. 2004. The biology and management of calico scale, Eulecanium cerasorum (Cockerell) (Hemiptera: Coccidae), in Kentucky. Ph.D. dissertation, University of Kentucky, Lexington.
Hubbard, J.L., and D.A. Potter. 2005. Life history and natural enemy associations of calico scale (Homoptera: Coccidae) in Kentucky. Journal of Economic Entomology 98: 1202-1212.

Johnson, W.T. 1982. The scale insect, a paragon of confusion. Journal of Arboriculture 8:113-123.

McClure, M.S. 1992. Effects of implanted and injected pesticide and fertilizers on the survival of Adelges iwgae (Homoptera: Adelgidae) and on the growth of Tsuga canadensis. Journal of Economic Entomology 85: 468-472.

Potter, D.A., L. Foss, R.E. Baumler, and D.W. Held. 2005. Managing eastern tent caterpillars, Malacosoma americanum (F.), on horse farms to reduce risk of mare reproductive loss syndrome. Pest Management Science 61:3-15.

Raupp, M.J., J.J. Holmes, C. Sadof, P. Shrewsbury, and J.A. Davidson. 2001. Effects of cover sprays and residual pesticides on scale insects and natural enemies in urban forests. Journal of Arboriculture 27(4):203-214.

Raupp, M.J., R.E. Webb, A. Szczepaniec, D. Booth, and R. Ahern. 2004. Incidence, abundance, and diversity of mites on hemlocks following applications of imidacloprid. Journal of Arboriculture 30:108-113.

Rebek, E.J., and C.S. Sadof. 2003. Effects of pesticide applications on the euonymus scale (Homoptera: Diaspididae) and its parasitoid, Encarsia citrina (Hymenoptera: Aphelinidae). Journal of Economic Entomology 96: 446-452.

Sclar, D.C., and W.S. Cranshaw. 1996. Evaluation of new systemic insecticides for elm insect pest control. Journal of Environmental Horticulture 14:22-26.

Steward, V.B., and T.A. Horner. 1994. Control of hemlock woolly adelgid using soil injections of systemic insecticides. Journal of Arboriculture 20:287-288.

Tattar, T.A., J.A. Dotson, M.S. Ruizzo, and V.B. Steward. 1998. Translocation of imidacloprid in three tree species when trunk- and soil-injected. Journal of Arboriculture 24:54-56.

Turner, J.C.L., and E.A. Buss. 2005. Biology and management of Allokermes kingii (Hemiptera: Kermesidae) on oak trees (Quercus spp.). Journal of Arboriculture 31: 198-202.

Young, L.C. 2002. The efficacy of micro-injected imidacloprid and oxydemeton-methyl on red gum eucalyptus trees (Eucalyptus camaldulensis) infested with red gum lerp psyllid (Glycapsis brimblecombei). Journal of Arboriculture 28:144-147.

Jamee L. Hubbard

(formerly) Graduate Research Associate

Department of Entomology

University of Kentucky

Lexington, KY 40546-0092, U.S. 
(currently) Assistant Professor

Department of Biology

167 CNR

University of Wisconsin-Stevens Point

Stevens Point, WI 54481, U.S.

Jamee.Hubbard@uwsp.edu

Daniel A. Potter (corresponding author)

Professor

Department of Entomology

S-225 Agricultural Science Building N

University of Kentucky

Lexington, KY 40546-0092, U.S.

Résume. L'Eulecanium cerasorum (Cockerell), un insecte généralisé chez les arbres ornementaux, a atteint des niveaux épidémiques dans les aménagements paysagers et les fermes chevalines du Kentucky. Nous avons évalué l'efficacité et la périodicité d'insecticides foliaires conventionnels et à faibles risques tout comme l'injection dans le tronc ou le sol de produits systémiques pour gérer le problème du E. cerasorum. L'acephate, le bifenthrin, le carbaryl, le cyfluthrin et le pyriproxyfen détruisaient les jeunes larves qui se déposaient sur les pousses vaporisées individuellement. Par contre, les vaporisations sur l'ensemble de la cime de pyrethroid ne donnaient qu'un contrôle inférieur à $66 \%$, ce qui rendait difficile d'atteindre l'objectif de contrôler les jeunes larves déposées sur les grands arbres matures. L'huile horticole et le savon insecticide étaient relativement inefficaces, même avec une vaporisation complète de l'arbre. Les vaporisations préventives avec le bifenthrin ou le pyriproxyfen à la mi-mai, lors de la première éclosion des œufs, interceptait les larves avant qu'elles ne puissent se déposer sur les feuilles. L'huile de dormance ne réussissait pas à contrôler l'hibernation des nymphes ou à réduire le nombre subséquent d'adultes ou de larves. L'application d'un antidessicant à la fin mars permettait d'obtenir 33\% de destruction. L'injection par le tronc d'imidacloprid était inefficace tandis que le dicrotophos (bidrin) donnait au mieux moins de 50\% de contrôle. L'injection par le sol d'imidacloprid en novembre, décembre ou en mars s'est avérée un échec pour réduire les densités subséquentes d'adultes sur les branches ou de larves sur les feuilles. Les raisons qui font qu'il était difficile d'éliminer cet insecte chez les arbres matures dans les aménagements paysagers sont discutées en fonction du contexte des sites d'alimentation de ce parasite et aussi de son comportement.
Zusammenfassung. Eulecanium cerasorum (Cockerell), ein invasives Schadinsekt auf Schattenbäumen hat in Kentucky in der Landschaft und auf Pferdefarmen einen Schwellenwert erreicht. Wir bewerteten die Effektivität und die Zeitabfolge von konventionellen und risikominimierten Insektiziden, sowie stamm-injizierte oder über den Boden applizierte systemische Pestizide, um dieses Insekt zu kontrollieren. Acephat, Bifenthrin, Carbaryl, oder Cyfluthrin, und Pyriproxyfen töteten die jungen Insekten auf den individuell behandelten Trieben. Pflanzenöl oder Pflanzenseife waren beide relativ ineffektiv, auch bei voller Pflanzenbedeckung. Vorsorgliche Sprühungen mit Bifenthrin oder Pyriproxyfen um Mitte Mai beim Schlüpfen der ersten Eier fingen die ersten Insekten ab, bevor sie sich auf den Blättern niederließen. Winteröl versagte bei der Kontrolle von den Überwinterungsstadien oder reduzierte die Anzahl der erwachsenen Stadien. Ein Anti-Transpirant, ausgebracht in Mitte März, lieferte $33 \%$ Verminderung. In den Stamm injiziertes Imidacloprid war ineffektiv, aber Dicrotophos erreichte als bestes über $50 \%$ Kontrolle. Die Bodeninjektion mit Imidacloprid im November, Dezember oder März versagte bei der Reduktion von nachfolgenden Bevölkerungsdichten von geschlüpften Insekten auf den Ästen bzw. auf den Blättern. Gründe, warum es so schwierig ist, dieses Insekt auf ausgewachsenen Bäumen in der Landschaft zu kontrollieren, werden hier im Zusammenhang mit den Fress- und Lebensgewohnheiten der Insekten kontrolliert.

Resumen. La escama Eulecanium cerasorum (Cockerell), una plaga invasiva de los árboles de sombra, ha alcanzado niveles epidémicos en los paisajes y granjas equinas en Kentucky. Se evaluó la eficacia y duración del efecto de insecticidas convencionales foliares, como también inyecciones al tronco o sistémicos aplicados al suelo para manejar E. cerasorum. Acefato, bifenthrin, carbaryl o cyfluthrin y pyriproxyfen acabaron con insectos jóvenes en brotes individualmente tratados. Las aspersiones a toda la copa con piretroides, sin embargo, dieron $<66 \%$ de control, indicando la dificultad de alcanzar la plaga en grandes árboles. El aceite hortícola y jabones insecticidas fueron relativamente inefectivos aun con una amplia cobertura de aplicación. Los spray preventivos con bifenthrin o pyriproxyfen a mediados de Mayo, al principio de la eclosión de huevillos, interceptó los insectos antes de que se localizaran en las hojas. El aceite falló para controlar las ninfas o reducir el subsiguiente número de adultos. Un antitranspirante aplicado en Marzo proporcionó 33\% de supresión. El imidacloprid inyectado al tronco fue inefectivo, mientras que dicrotophos (bidrin) dio un mejor $<50 \%$ de control. La inyección al tronco con imidacloprid en Noviembre, Diciembre o Marzo falló para reducir las densidades subsecuentes de adultos en ramas u hojas. Se discuten las razones de por qué es difícil eliminar la escama en árboles maduros en el contexto de los sitios de alimentación y el comportamiento de la plaga. 